\title{
Nitrite oxidizing bacteria (NOB) dominating in nitrifying community in full-scale biological nutrient removal wastewater treatment plants
}

\author{
Qian Yao ${ }^{1,2^{*}}$ and Dang-Cong Peng ${ }^{1,2}$
}

\begin{abstract}
Nitrification activities and microbial populations of ammonium oxidizing bacteria (AOB) and nitrite oxidizing bacteria (NOB) were investigated in 10 full-scale biological nutrient removal wastewater treatment plants in Xi'an, China. Aerobic batch tests were used to determine the nitrifying activities while fluorescence in situ hybridization was used to quantify the fractions of $A O B$ and $N O B$ in the activated sludge. The results showed that nitrifying bacteria accounted for $1-10 \%$ of the total population. Nitrosomonas and Nitrospira were the dominant bacteria for AOB and NOB respectively. Moreover, the average percentage of AOB was $1.27 \%$ and that of NOB was $4.02 \%$. The numerical ratios of NOB/ $A O B$ varied between 1.72 and 5.87. The average ammonium uptake rate and nitrite uptake rate were $3.25 \pm 0.52 \mathrm{mg}$ $\left(\mathrm{NH}_{4}{ }^{+}-\mathrm{N}\right) / \mathrm{g}$ (VSS) $\mathrm{h}$ and $4.49 \pm 0.49 \mathrm{mg}\left(\mathrm{NO}_{2}{ }^{-}-\mathrm{N}\right) / \mathrm{g}$ (VSS) $\mathrm{h}$, respectively. Correspondingly, the activity of NOB was 1.08-2.00 times higher than that of AOB. Thus, NOB was the dominating bacteria in nitrifying communities. The yearround data of Dianzicun (W6) also expressed a similar trend. Since NOB had higher activities than that of AOB, a large nitrite oxidation pool could be formed, which guaranteed that no nitrite would be accumulated. Therefore, stable nitrification could be achieved. A conceptual model was proposed to describe the population variation of $A O B$ and NOB in a nitrifying community.
\end{abstract}

Keywords: Nitrifying community, Biological nutrient removal, FISH, Activity, Dominating

\section{Introduction}

Nitrification is of great importance for nitrogen removal from municipal wastewater in the biological nutrient removal process (BNR) employed in waste water treatment plants (WWTPs). In nitrification, ammonium is firstly oxidized to nitrite via ammonia-oxidizing bacteria $(\mathrm{AOB})$, and then to nitrate by nitrite-oxidizing bacteria (NOB). However, due to low biomass yield and sensitivity to environmental factors, nitrifying bacteria only account for a small fraction of total biomass. Although nitrifying bacteria populations are generally within the range of $4-6 \%$ of biomass for adequate nitrification in nutrient

\footnotetext{
*Correspondence: qianyao@hotmail.com

${ }^{1}$ School of Environmental and Municipal Engineering, Xi'an University of Architecture and Technology, Yanta Road 13, Xi'an 710055, China Full list of author information is available at the end of the article
}

removal facilities (Nielsen et al. 2004), a wide variation of the fraction of nitrifying bacteria in microbial communities has been reported. It varies from $0.39 \%$ in activated sludge (Dionisi et al. 2002), to $9 \%$ in a nitrifying activated sludge SBR reactor (Li et al. 2007), and even to over 18\% in a combined activated sludge and rotating biological contactor (You et al. 2003). The difference of the percentage of nitrifying bacteria may be affected by operational conditions and influent qualities.

Theoretically, the numerical ratio of $\mathrm{AOB}$ to $\mathrm{NOB}$ in a balanced nitrifying system should be 2:1 according to thermodynamics and electron transfer (Arciero et al. 1991; Hooper et al. 1997; Mari et al. 2012), which means that $\mathrm{AOB}$ should be the dominant bacteria in a nitrifying community. Li et al. (2007) found that the AOB to NOB ratio in a sufficient nitrification process was $2.2-2.7$. In a similar result, You et al. (2003) reported the percentage 
of $\mathrm{AOB}$ was 2.0-3.5 times higher than NOB. However, there were some exceptions demonstrating that, from time to time, a disproportion in the ratios of $\mathrm{AOB} / \mathrm{NOB}$ existed. Ramdhani et al. (2013) investigated the nitrifying bacteria communities at two full-scale domestic wastewater treatment plants in South Africa: lower AOB/NOB ratios were detected, 1.0-1.5 in Kingsburgh WWTP and $0.8-1$ in Darville WWTP. Harms et al. (2003) found NOB (Nitrospira) could reach more than three times higher than $\mathrm{AOB}$ in a municipal wastewater treatment plant. Moreover, in the lab and pilot studies of Mari et al. (2012), an elevated NOB/AOB ratio (3-4) was observed in an aerobic granular sludge sample. These controversial data suggest that more investigations are needed.

Due to the sequential oxidation property, the growth balance between AOB and NOB plays a key role in optimization of a nitrifying community. If $\mathrm{AOB}$ grows more quickly than $\mathrm{NOB}$, and the ammonium oxidizing rate is higher than nitrite oxidizing rate, nitrite as an intermediate will be easily accumulated. Nitrite is toxic to aquatic ecosystems and poses potential threats to human health security. Furthermore, nitrite will be converted under anoxic condition by Nitrosomonas to nitrous oxide $\left(\mathrm{N}_{2} \mathrm{O}\right)$ (Colliver and Stephenson 2000), which is a lethal greenhouse gas (GHG) causing ozone depletion. Therefore, fully understanding the population and interaction of $\mathrm{AOB}$ and $\mathrm{NOB}$ in the nitrifying community is very important to optimize nitrification in biological nutrient removal plants.

In this study, 10 full-scale biological nutrient removal plants in Xi'an, China, were investigated in terms of process efficiency, nitrification activity and the nitrifying community. Nitrification activity in each WWTP was evaluated by aerobic batch tests using fresh activated sludge. The fractions of $\mathrm{AOB}$ and $\mathrm{NOB}$ and the dominating bacteria were determined by fluorescence in situ hybridization (FISH). The objectives were to attempt to answer the following questions: (1) How do $\mathrm{AOB}$ and NOB distribute in full-scale biological nutrient removal WWTPs? (2) What is the real ratio of $\mathrm{AOB}$ and NOB in nitrifying communities in treatment plants? (3) How do nitrifying bacteria communities interact with operational processes and parameters?

\section{Materials and methods}

\section{Plants and sampling}

Ten biological nutrient removal plants in Xi'an, China were investigated: Dengjiacun (W1), Dengcun (W2), Beishiqiao (W3), Bshiq (W4), Fangzhicheng (W5), Dianzicun (W6), Yuanlecun (W7), Liucunbao (W8), Gaoxin (W9) and Chang'an (W10). They were located in different areas and received both domestic and industrial wastewaters. W1 and W2 shared one sewer and had the same influent composition. Information related to plant process configurations, influent/effluent wastewater compositions and operation parameters was directly obtained by reviewing plant documents, interviewing plant operators and visiting WWTPs facilities. Operational data and treatment efficiencies are compiled in Table 1.

Fresh activated sludge was collected from the final stage of the aeration basin in each plant on September 5th, 15th and 25th, 2015, respectively. During the survey period, water temperature varied from 20 to $25^{\circ} \mathrm{C}$. Samples in W6 were collected monthly for over a year (from January 2015 to March 2016). All samples were stored in an ice box and kept at $4{ }^{\circ} \mathrm{C}$ during transportation. For fluorescence in situ hybridization analysis, sludge was fixed immediately upon arrival in $4 \%$ paraformaldehyde (PFA) for $3 \mathrm{~h}$ at $4{ }^{\circ} \mathrm{C}$ and stored in phosphate-buffered saline $/ 96 \%$ Ethanol $(1: 1, \mathrm{vol} / \mathrm{vol})$ at $-20{ }^{\circ} \mathrm{C}$. Additional sludge aliquots were tested immediately in the lab for nitrifying activity.

\section{The activity of nitrifying bacteria}

Monitoring the activity of nitrifying bacteria was carried out by two methods: oxygen uptake rates (OUR) and substrate uptake rates (SUR).

Oxygen uptake rates were measured using a conventional respirometer (Strathkelvin 782) with $0.5 \mathrm{~mL}$ Mitocell (MT200A). Allylthiourea (ATU, $5 \mathrm{mg} / \mathrm{L}$ ) was added to inhibit the ammonia to be oxidized to nitrite. Sodium chlorate $\left(\mathrm{NaClO}_{3}, 2 \mathrm{~g} / \mathrm{L}\right)$ was added to inhibit the oxidation of nitrite to nitrate. The temperature was maintained at $25^{\circ} \mathrm{C}$ for all respiratory analysis. Prior to analysis, samples were elutriated and aerated to remove all soluble substances.

For the SURs test, ammonium chloride (20 mg $\mathrm{NH}_{3}-$ $\mathrm{N} / \mathrm{L}$ ) and sodium nitrous acid (30 $\mathrm{mg} \mathrm{NO}_{2}-\mathrm{N} / \mathrm{L}$ ) were used as the substrate to measure ammonium uptake rates (AUR) and nitrite uptake rates (NUR), respectively. During the whole test, temperature was maintained as the same for the OUR test, $25^{\circ} \mathrm{C}$. $\mathrm{NaHCO}_{3}$ was added to ensure a stable $\mathrm{pH}$. The mixed liquor was purged with air and spiked with substrate in the presence of the inhibitor. Then, samples were taken every $10 \mathrm{~min}$ and $\mathrm{NH}_{3}-\mathrm{N}$ and $\mathrm{NO}_{2}-\mathrm{N}$ were measured to calculate AUR and NUR respectively.

\section{Chemical analysis}

Ammonium, nitrite, nitrate, mixed liquor suspended solids (MLSS) and volatile MLSS (MLVSS) were determined according to Standard Methods (APHA 1995). Dissolved oxygen (DO) concentration was measured with an oxygen dissolving meter (SG6-FK10, Mettler Toledo). 


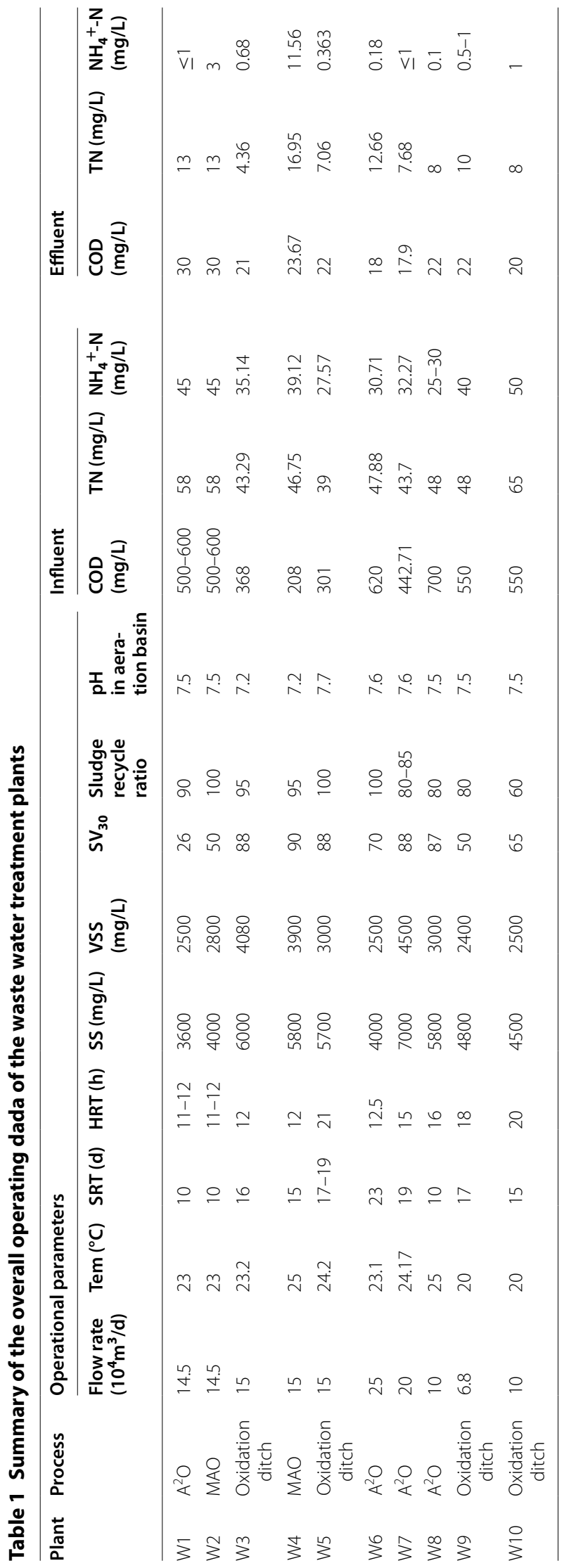




\section{Florescence in situ hybridization (FISH)}

Table 2 summarizes the $16 \mathrm{~S}$ rRNA-targeted oligonucleotide probes used in this study. Probe EUBmix (an equimolar mixture of EUB338, EUB338IIand EUB338III), labeled with Cy5, was used to target almost all bacteria. Probe AOBmix (a mixture of Nso1225, NEU, NmV and Cluster6a192), labeled with Flous, was used to target the AOB. Probe NOBmix (a mixture of Ntspa662, NIT3 and Ntspa712), labeled with $\mathrm{Cy} 3$, was used to detect NOB. Moreover, Nsm156 was specific for Nitrosomonas spp.; Nsv443 was specific for Nitrosospira spp.; Ntspa662 was specific for Nitrospira spp. and NIT3 was specific for Nitrobacter spp.

The hybridization of the activated sludge sample was performed according to the standard hybridization protocol described by Amann et al. (1990). $8 \mu \mathrm{L}$ of the hybridization buffer $(0.9 \mathrm{M} \mathrm{NaCl}, 20 \mathrm{mM}$ Tris- $\mathrm{HCl}$, $0.01 \%$ SDS and formamide [concentration has been given in Table 2]) and $1 \mu \mathrm{L}$ fluorescent probe $(50 \mathrm{ng} / \mu \mathrm{L})$ were placed on each well and mixed gently with a tip. The slide was then transferred into the prepared equilibrated chamber and hybridized for $1.5-2 \mathrm{~h}$ at $46^{\circ} \mathrm{C}$, after which it was washed at the hybridization temperature for $10 \mathrm{~min}$ in a washing buffer $(20 \mathrm{mM}$ Tris-HCl, $5 \mathrm{mM}$ EDTA and $\mathrm{NaCl}$ ) and rinsed with distilled water for $5 \mathrm{~s}$. After final air drying, the slide was mounted with a drop of Citiflour (Sigam, USA), covered with a coverslip and viewed immediately.

\section{Microscope and image analyze}

A confocal laser scanning microscope (CLSM; Leica SP8, Germany) equipped with one Ar-ion laser (488 nm, for detection of Flous) and two HeNe lasers (552 and
$638 \mathrm{~nm}$, for detection of Cy3 and Cy5 respectively) was used to examine the microbial community. Both stages of image combining and processing were performed with the process tools of the software delivered by the CLSM supplier. The image analysis was determined by using the software package PaintShopPro (Jasc, Eden Prairie, MN, USA).

For community testing, total 60 views were obtained for each WWTP (ten views for each well, two wells for each sample and three samples for each WWTP). All images were first processed with blur (or out-of-focus) removing, then three colors (Cy3-Red; Cy5-Blue; FlousGreen) were counted separately for each image. The proportions and numbers of the targeted nitrifiers were calculated according to Li et al. (2007) and Manser et al. (2006).

\section{Results}

\section{Operational data and performance}

Operating parameters and average influent and effluent characteristics for all WWTPs are shown in Table 1. Significant variations in influent characteristics (COD, TN and $\mathrm{NH}_{3}-\mathrm{N}$ ) were recorded. COD in W6 reached as high as $620 \mathrm{mg} / \mathrm{L}$, while in W4, it was as low as $260 \mathrm{mg} / \mathrm{L}$ during the survey. TN in the influent varied between 39 and $65 \mathrm{mg} / \mathrm{L}$ and $\mathrm{NH}_{3}-\mathrm{N}$ between 25 and $50 \mathrm{mg} / \mathrm{L}$. The fluctuations of influent characteristics reflected the developing sewer systems in the region.

Due to higher $\mathrm{COD} / \mathrm{N}$ ratios in the influent, high $\mathrm{TN}$ removal rates (63.74-89.93\%) were achieved in all of the plants investigated. Research has shown that simultaneous nitrification and denitrification (SND) will be stimulated in an Oxidation Ditch, which benefits high

Table 2 rRNA-targeted oligonucleotide probe used in this study

\begin{tabular}{|c|c|c|c|c|}
\hline Probe & Specific & Sequence $\left(5^{\prime}-3^{\prime}\right)$ & $\mathrm{FA}^{\mathrm{a}}(\%)$ & Reference \\
\hline EUB & & GCTGCCTCCCGTAGGAGT & & \\
\hline EUBII & Almost all bacteria & GCAGCCACCCGTAGGTGT & $0-80$ & Daims et al. (1999) \\
\hline EUBIII & & GCTGCCACCCGTAGGTGT & & \\
\hline Nso1225 & Betaproteobacterial ammonia-oxidizing bacteria & CGCCATTGTATTACGTGTGA & 35 & Mobarry et al. (1996) \\
\hline NEU & Most halophilic and halotolerant Nitrosomonas spp. & CССCTCTGCTGCACTCTA & $40^{b}$ & Wagner et al. (1995) \\
\hline $\mathrm{NmV}$ & Nitrosococcus mobilis & TCCTCAGAGACTACGCGG & 35 & Pommerening et al. (1996) \\
\hline Cluster6a192 & Nitrosomonas oligotropha lineage & CTTTCGATCCCCTACTTTCC & 35 & Adamczyk et al. (2003) \\
\hline Nsm156 & Nitrosomonas spp., Nitrosococcus mobilis & TATTAGCACATCTTTCGAT & 5 & Mobarry et al. (1996) \\
\hline Nsv443 & Nitrosospira spp. & CCGTGACCGTTTCGTTCCG & 30 & Mobarry et al. (1996) \\
\hline Ntspa712 & Phylum Nitrospirae & CGCCTTCGCCACCGGCCTTCC & $50^{c}$ & Daims et al. (2001) \\
\hline Ntspa662 & Genus Nitrospira & GGAATTCCGCGCTCCTCT & 35 & Daims et al. (2001) \\
\hline NIT3 & Genus Nitrobacter & CCTGTGCTCCATGCTCCG & 40 & Wagner et al. (1996) \\
\hline
\end{tabular}

a FA formamide

b NEU can also be used with 35\% FA

c Ntspa712 can also be used with 35\% FA, especially if combined with Ntspa662 
TN removal (Zhou et al. 2013). In this research, similar results were observed. TN removal rates in an Oxidation Ditch seemed to be higher than that in $\mathrm{A}^{2} / \mathrm{O}$. In addition, although a wide range of SRT (10-23 days) and HRT (11-20 h) were employed, $\mathrm{NH}_{3}-\mathrm{N}$ concentrations in the effluent were less than $3 \mathrm{mg} / \mathrm{L}$ in all plants except W4, in which DO concentration in the aeration basin was low. These results suggest that good nitrification was achieved. Excellent nitrification performance meant that stable nitrifying communities were built and a solid foundation for the investigation was established.

\section{Morphology and spatial distribution of nitrifying bacteria}

To investigate the spatial distribution and morphology of nitrifying bacteria, FISH was carried out for all sludge samples. The results showed that nitrifying bacteria were not uniformly distributed in the activated sludge (Fig. 1 for W7 and W6. For others, see Additional file 1: Figure $\mathrm{S1}$ ). Both $\mathrm{AOB}$ and NOB were found to be aggregated in spherical or irregular microcolonies. $\mathrm{NOB}$ exhibited in a denser and smaller microcolony $(2-12 \mu \mathrm{m})$, but $\mathrm{AOB}$ exhibited in a looser and bigger microcolony $(5-25 \mu \mathrm{m})$.

Concerning space distribution, nitrifying bacteria grew inside the flocs while heterotrophic bacteria grew outside. This spatial distribution character reflected their competition for oxygen in the bulk. Typically, heterotrophic bacteria have a higher oxygen affinity and growth rate than that of nitrifying bacteria (Pambrun et al. 2006). Therefore, heterotrophic bacteria will grow quickly and are present outside the flocs. In addition, NOB colonies were located in the vicinity of $\mathrm{AOB}$ colonies according to the results. This co-occurrence of $\mathrm{AOB}$ and $\mathrm{NOB}$ has been confirmed in the studies of nitrifying bacteria in biofilm and activated sludge (Okabe et al. 1996), which can minimize the diffusion distance of the intermediate and reflect the syntrophic association between $\mathrm{AOB}$ and NOB (Mobarry et al. 1996).

\section{Activity and quantity of nitrifying bacteria in ten WWTPs}

Nitrification activities in 10 WWTPs are shown in Fig. 2. The OURs of AOB ranged from 9.58 to $22.35 \mathrm{mg}\left(\mathrm{O}_{2}\right) /$ $\mathrm{g}$ (VSS) h, and were 1.70-3.74 times higher than that of NOB (Fig. 2a). In the sequential reaction, the oxygen demand for the ammonium oxidation step and nitrite oxidation step are usually $3: 1$, thus AOB had a higher OUR than NOB. However, stoichiometrically, six electrons are needed for oxidizing one mole of ammonium to nitrite, but only two for nitrite to nitrate. This may result in that AUR was lower than NUR in turn. The direct detection of AUR and NUR also reflected the same trend (Fig. 2b). The average AUR and NUR were $3.25 \pm 0.52 \mathrm{mg}\left(\mathrm{NH}_{4}{ }^{+}-\right.$ $\mathrm{N}) / \mathrm{g}(\mathrm{VSS}) \mathrm{h}$ and $4.49 \pm 0.49 \mathrm{mg}\left(\mathrm{NO}_{2}{ }^{-}-\mathrm{N}\right) / \mathrm{g}(\mathrm{VSS}) \mathrm{h}$, respectively. The highest $\mathrm{AOB}$ and $\mathrm{NOB}$ activities were observed in W1 while W4 had the lowest AUR and NUR, in which DO concentration in the aeration basin was measured to be $0.5-1 \mathrm{mg} / \mathrm{L}$.

The relative amounts of the targeted bacteria were calculated as the percentage of the total biomass by using FISH. The results are shown in Fig. 3. Nitrifying bacteria accounted for $1-10 \%$ (average, $5.29 \pm 2.11 \%$ ) of the total biomass in the WWTPs surveyed. Five of them ranged from 4 to $6 \%$, a typical nitrifying bacteria proportion in
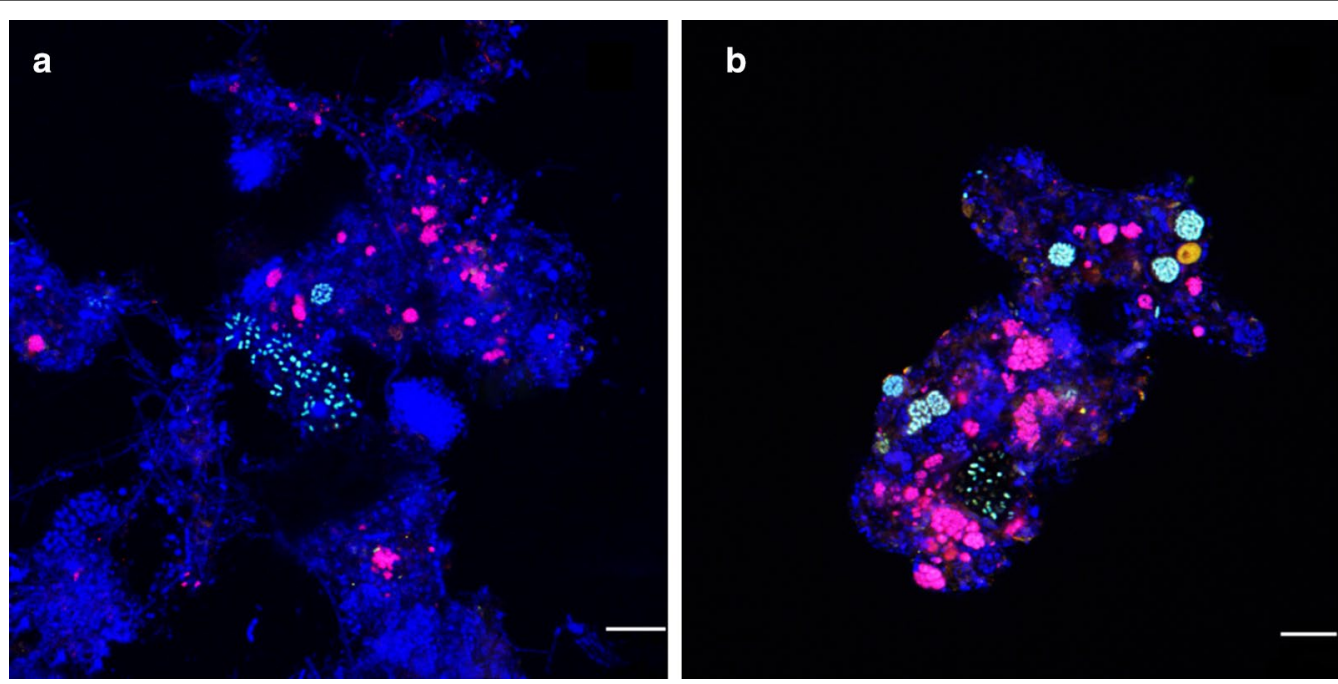

Fig. 1 In situ hybridization of activated sludge. In situ hybridization of activated sludge with Cy5-labeled probe EUBmix, Flous-labeled probe AOBmix and Cy3-labeled probe NOBmix (a is the activated sludge from W7 and $\mathbf{b}$ is from W6). Blue EUBmix-stained Eubacteria; cyan AOBmix-stained $\mathrm{AOB}$; carmine NOBmix-stained NOB; Bar $10 \mu \mathrm{m}$ 


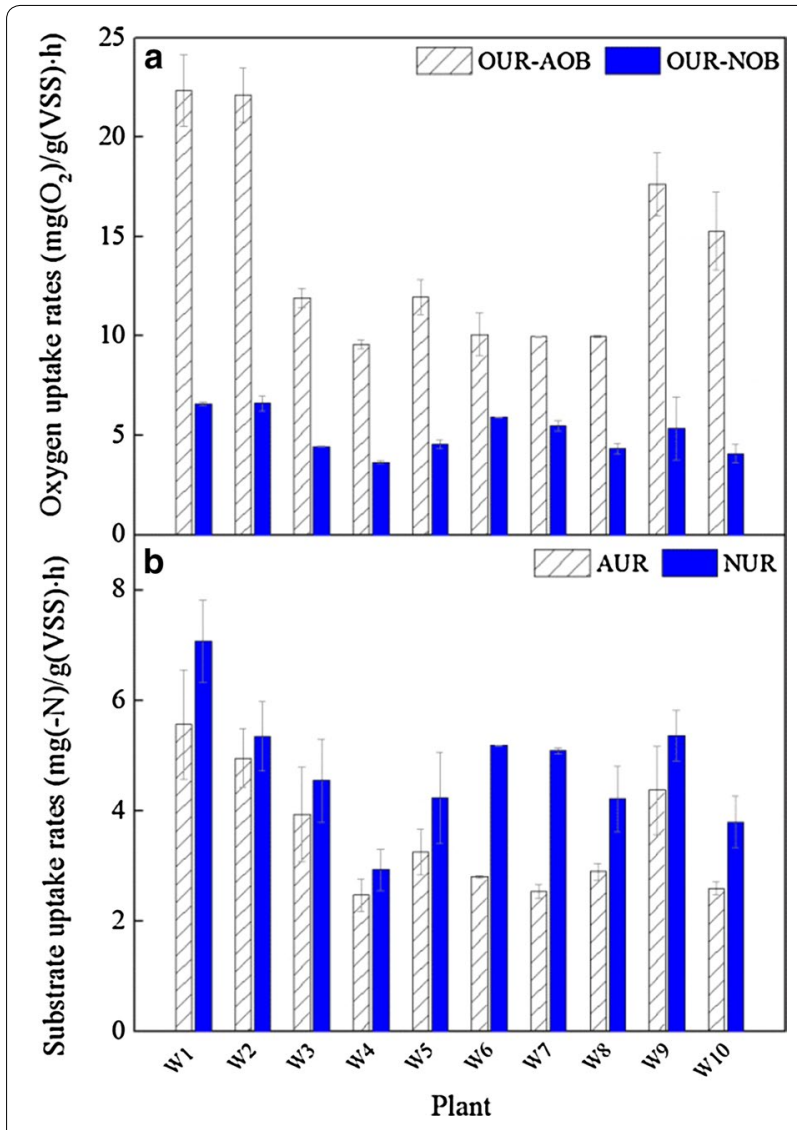

Fig. 2 Nitrifying activity in 10 WWTPs. a oxygen uptake rates of $A O B$ (OUR-AOB) and NOB (OUR-NOB); b ammonium uptake rates for $A O B$ (AUR) and nitrite uptake rates for NOB (NUR)

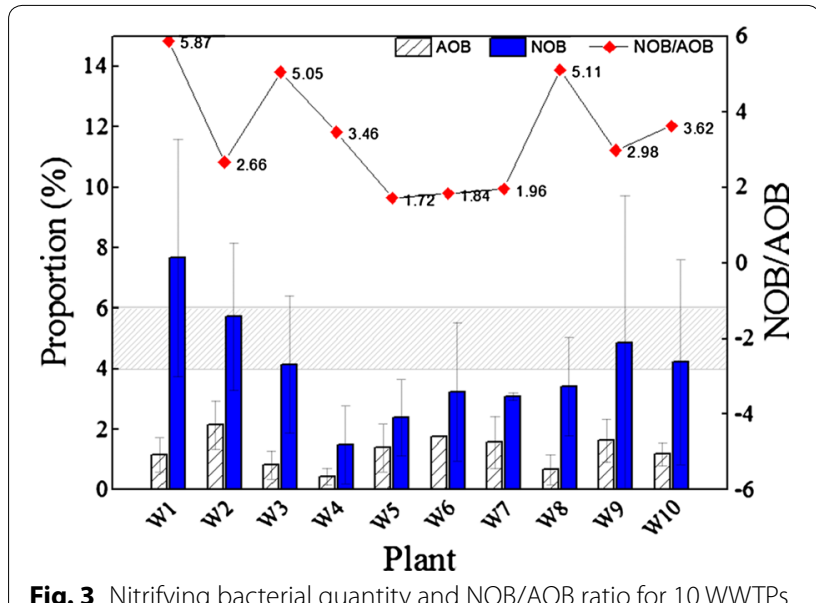

biological nutrient removal plants as Nielsen et al. (2004) reported. The nitrifying bacteria in W4 presented the lowest percentage $(1.82 \pm 1.69 \%)$ with $0.43 \pm 0.28 \%$ of $\mathrm{AOB}$ and $1.49 \pm 1.28 \%$ of $\mathrm{NOB}$ in biovolume. Whereas
W1 had the highest percentage of nitrifying bacteria of $8.97 \pm 3.86 \%$ and $\mathrm{AOB}$ and $\mathrm{NOB}$ accounted for $1.15 \pm 0.57$ and $7.67 \pm 3.91 \%$ respectively. The quantities of nitrifiers were consistent with the nitrifying activities in batch tests. The higher percentage of a targeted microbe in a mixed culture, the higher activity of the mixed culture will be observed. However, in our results, no clear linear correlation was suggested. In addition, FISH results showed that the ratios of $\mathrm{NOB} / \mathrm{AOB}$ varied from 1.72 to 5.87 . NOB dominated in the nitrifying bacteria community in all the WWTPs surveyed.

\section{Activity and quantity of nitrifying bacteria in W6}

FISH test displayed a significant amount of AOB (average of $2.36 \%$ ) and NOB (average of $4.28 \%$ ) from January 2015 to March 2016 (Fig. 4) in W6. The NOB/AOB ratio fluctuated throughout the study period and ranged from 1.25 to 2.46 (Fig. 4b). An overall higher NOB proportion was noted when compared with AOB. During the investigated periods, the higher activity of nitrifying bacteria occurred from June to August 2015. This may have been caused by the higher summer temperature $\left(20-30{ }^{\circ} \mathrm{C}\right)$, which is sufficient to ensure the complete

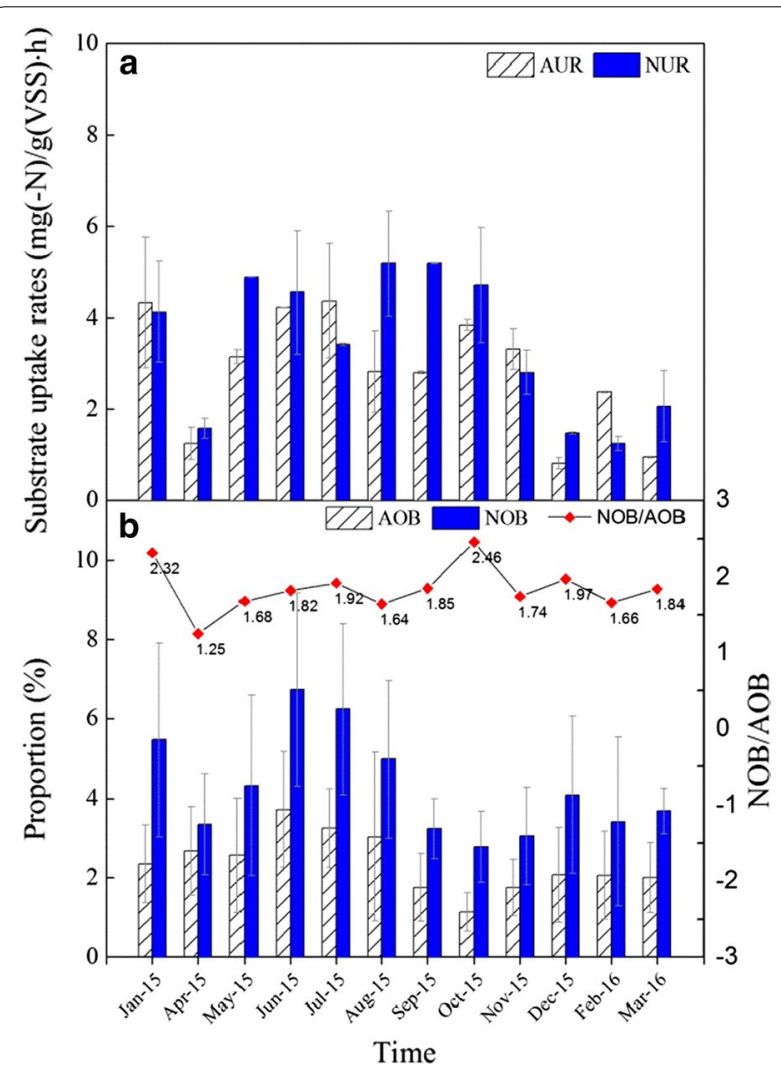

Fig. 4 Year-round data for the activity and quantity of nitrifying bacteria in W6. a nitrifying activity; $\mathbf{b}$ proportion of $\mathrm{AOB}$ and $\mathrm{NOB}$ 
growth of nitrifying bacteria and the establishment of stable communities of AOB and NOB (Hao et al. 2002). As expected, both of the AUR and NUR decreased during winter (from December to February). Since NOB is more sensitive to lower temperature, the NUR decreased $48 \%$ when compared with that in summer, while AUR only decreased $34 \%$. Moreover, the proportion of $\mathrm{AOB}$ and NOB also showed a remarkable decline in the winter. However, it must be addressed here that the proportion of NOB declined no more than AOB. This was caused by the specific growth rate of $\mathrm{NOB}$ which was higher than that of AOB, between 5 and $15^{\circ} \mathrm{C}$. It is known that NOB dominates $\mathrm{AOB}$ at temperatures below $15{ }^{\circ} \mathrm{C}$ (Zhu et al. 2008).

\section{Population structure of nitrifying bacteria}

Different combinations of 16SrRNA-targeted oligonucleotide probes were used to characterize nitrifying population structures in the activated sludge for either Nitrosomonas spp. or Nitrosospira spp. of AOB and Nitrobacter spp. or Nitrospria spp. of NOB. The results are shown in Additional file 1: Figure S2. In most WWTPs, Nitrosomonas and Nitrospria were found to be the dominant bacteria with a fraction of $0.42-1.53$ and $1-4.96 \%$ of total biomass, which accounted for $63-97.70 \%$ of AOB and $60-91.71 \%$ of NOB, respectively. Nitrosospira-like AOB and Nitrobacter-like NOB could only be detected in some samples and accounted for $0-0.35$ and $0-0.53 \%$ of the total biomass (Additional file 1: Figure S3). Additionally, it is worth noting that neither Nitrospira nor Nitrobacter was the dominant nitrite oxidizer in W3, suggesting that some other species of NOB was also important in the activated sludge. In the studies of Lücker et al. (2014) and Saunders et al. (2015), Nitrotoga were numerically abundant in the activated sludge plants in Austria and Denmark, which challenged the previous assumptions that Nitrospira was the dominant nitrite-oxidizers in activated sludge.

\section{Discussion}

\section{Dominant bacteria responding to different treatment} processes

Nitrifying community structures in activated sludge of 10 WWTPs were analyzed by FISH. Four major groups of nitrifying bacteria which were frequently reported to exist in WWTPs were detected. According to the results, no significant difference was revealed in the dominant nitrifying bacteria in 10 WWTPs. Nitrosomonas spp. and Nitrospira spp. were found to be the dominant nitrifying bacteria in most systems. This finding supports the point that Nitrospria-like NOB, as a K strategist, could thrive in a low nitrite environment, especially in most municipal WWTPs (Dionisi et al. 2002; Freitag et al. 2005; Off et al. 2010). Additionally, consistent with most previous studies (Wagner et al. 1996), Nitrosospira was not the most important bacteria in WWTPs, and was not even detected in some samples. Nitrosomonas (such as $N$. europaea), which grow more quickly than Nitrosospira spp. (Siripong and Rittmann 2007) can outcompete Nitrosospira as the prevailing group in the activated sludge of full-scale wastewater treatment plants.

In the study of Wang et al. (2014), nine operational and environmental variables were tested to determine the factors that shaped microbial community structure in WWTPs. Among them, DO, temperature and ammonium concentration were the important variables strongly influencing the microbial community and this result was consistent with the findings of Wells et al. (2009), Gregory et al. (2010) and Szukics et al. (2010). However, in the 10 WWTPs surveyed in this study, almost all WWTPs were operated similarly involved ammonium concentration, temperatures and DO concentrations (about $2 \mathrm{mg} / \mathrm{L}$ in the 10 WWTPs). Moreover, although they were operated with different treatment processes, they all use the activated sludge system. Therefore, there was no selection pressure which gave rise to the change of domination bacteria in the nitrifying community. But, it worth noting, there were still some exceptions in W3 and W5 where Nitrospira and Nitrosomonas were not the dominating bacteria respectively. This result may be caused by the fact that selection had already begun in the sewers, and there were some other organisms acting as a seed for selection.

\section{Activity of nitrifying bacteria}

Activity is generally used to describe the maximum substrate utilization potential of targeted microorganisms in a community. The higher percentage of a targeted microbe in a mixed culture, the higher activity of the mixed culture will be observed.

With FISH technology, the number of a targeted microbe in a mixed culture can be counted. In our study, AOB cell numbers ranged between $4.3 \times 10^{9}$ and $2.42 \times 10^{10} \mathrm{cell} / \mathrm{L}$ and NOB was in the range of $1.49-7.67 \times 10^{10}$ cell/L. Therefore, the real activity of the targeted microbe can be estimated as the following equations:

$$
\begin{aligned}
& \text { Specific activity for mass }[\mathrm{mg}(\mathrm{N}) / \mathrm{g} \text { AOB }(\mathrm{NOB}) \mathrm{h}] \\
= & \frac{\text { Activity }(\mathrm{mg} \mathrm{N} / \mathrm{gVSS} \mathrm{h})}{\text { Fraction of AOB or NOB } \% \text { biomass })} \\
& \text { Specific activity for a cell } \\
= & \frac{\text { Activity }(\mathrm{mg} \mathrm{N} / \mathrm{gVSS} \mathrm{h})}{\text { Number of AOB or NOB (cell/L) }} .
\end{aligned}
$$

Table 3 shows the specific activities of nitrifying bacteria reported in the relevant literatures and our study. The specific activity for cells varied remarkably in the WWTPs. The average specific activity for cells of $\mathrm{AOB}$ 
Table 3 Specific activity of AOB and NOB in lab-scale and full-scale WWTPs

\begin{tabular}{|c|c|c|c|c|}
\hline \multirow[t]{2}{*}{ Reference } & \multicolumn{2}{|l|}{ AOB } & \multicolumn{2}{|l|}{ NOB } \\
\hline & (mg-N/gAOB/h) & (fmol-N/cell/h) & (mg-N/gNOB/h) & (fmol-N/cell/h) \\
\hline Our study (average) & $321.94 \pm 154.19$ & $22.99 \pm 11.01$ & $132.028 \pm 39.06$ & $9.43 \pm 2.79$ \\
\hline \multicolumn{5}{|l|}{ Other studies } \\
\hline \multicolumn{5}{|l|}{ Full-scale } \\
\hline Limpiyakorn et al. (2005) & - & $0-49.6$ & - & - \\
\hline Harms et al. (2003) & - & $7.7 \pm 6.8$ & - & - \\
\hline Daims et al. (2001) & - & $16-43$ & - & - \\
\hline Fujita et al. (2010) & - & $1.1-11.9$ & - & $2.4-21.6$ \\
\hline Belser and Schmidt (1980) & - & $9-123$ & - & - \\
\hline \multicolumn{5}{|l|}{ Lab-scale } \\
\hline Copp and Murphy (1995) & 175 & - & - & - \\
\hline Sun (2004) & 109 & - & - & - \\
\hline Hanaki et al. (1990) & 70 & - & - & - \\
\hline
\end{tabular}

in our study was $22.99 \pm 11.01 \mathrm{fmol}-\mathrm{N} /$ cell h, which was consistent with the results reported by Daims et al. (2001) and Limpiyakorn et al. (2005). However, it was higher than that reported in lab-scale reactors. In fact, microorganisms have different growth rates during different growth phases. If longer SRT is employed, the bacteria as a whole will grow in a "stationary phase". The lower activity will be observed. Therefore, due to longer SRTs (20-22 days), the activities of AOB in lab-scale WWTPs (Hanaki et al. 1990; Copp and Murphy 1995; Sun 2004) were lower than in our study. Similarly, in the surveyed WWTPs, W6 and W7 had longer SRTs (20 and 19 days) and lower specific activities (159.79 and $160.33 \mathrm{NH}_{4}{ }^{+}-\mathrm{N} /$ gAOB $h$, respectively) were detected. Whereas both W1 and W8 had shorter SRTs (10 days), the specific activities of AOB were 483.14 and $434.62 \mathrm{NH}_{4}{ }^{+}-\mathrm{N} / \mathrm{gAOB} \mathrm{h}$, respectively. As for NOB, the average specific activity for cells was $9.43 \pm 2.79 \mathrm{fmol}-\mathrm{N} / \mathrm{cell} \mathrm{h}$, which was nearly the same as the value Fujita et al. (2010) reported.

\section{NOB dominating in nitrifying community}

Our research demonstrated an elevated NOB/AOB ratio $(1.25-5.9)$ in 10 full-scale biological nutrient removal wastewater treatment plants, which was much higher than the expected ratio of 0.5 based on the electron transfer for bacterial growth in nitrification. Why was NOB abundant with so high a percentage in a nitrifying community? There must be an access that the growth of NOB does not rely on the nitrite provided by AOB. In order to explain this phenomenon, we constructed a conceptual model to describe the bacterial growth balance in a nitrifying community (Fig. 5). Nitrification is normally coupled with denitrification to convert ammonium to dinitrogen gas. If nitrification and denitrification take place independently, nitrite produced by $\mathrm{AOB}$ will be used completely by NOB. The growth balance of $A O B$ and $\mathrm{NOB}$ can be reached. The numerical ratio of $\mathrm{AOB} /$ NOB should be 2 as shown in Fig. 5b. Where there is a competition between nitrite oxidation by NOB and nitrite reduction by nitrite reducing bacteria (NiRB), part of nitrite produced by $\mathrm{AOB}$ will be reduced to nitrogen gas by NiRB. The substrate (nitrite), which should be used for NOB, will be reduced. The numerical ratio of AOB/NOB should be more than 2 (Fig. 5a). In the studies of You et al. (2003), Fujita et al. (2010) and Mari et al. (2012), AOB/NOB ratios were revealed to be 3-10 in nitrifying communities at wastewater treatment plants. However, there is also a case where nitrite oxidation is coupled with nitrate reduction as described by Mari et al. (2012). A nitrite loop will be formed. Additional substrate (nitrite) could be provided by nitrate reducing bacteria (NaRB) for NOB growth. The number of NOB in the community will be more than that in Fig. 5b, and the ratio of $\mathrm{AOB} / \mathrm{NOB}$ will be less than 2 as shown in Fig. 5c.

This model can well explain the higher percentage of NOB in our study. In full-scale biological nutrient removal wastewater treatment plants, due to high loading rates, DO concentrations were observed to be $1-2 \mathrm{mg} / \mathrm{L}$ in aerobic basins, which limited the diffusion of oxygen in the activated sludge flocs with larger diameters. Therefore, the aerobic region was limited to the surface layer, and an anoxic zone could exist inside the flocs (Takacs and Fleit 1995; De et al. 1998; Li and Bishop 2003). The anoxic zone created an environment in which the reduction of nitrate by NaRB could take place. Excess substrate was supplemented for $\mathrm{NOB}$ and the percentage of NOB in the nitrifying community in the flocs increased. 


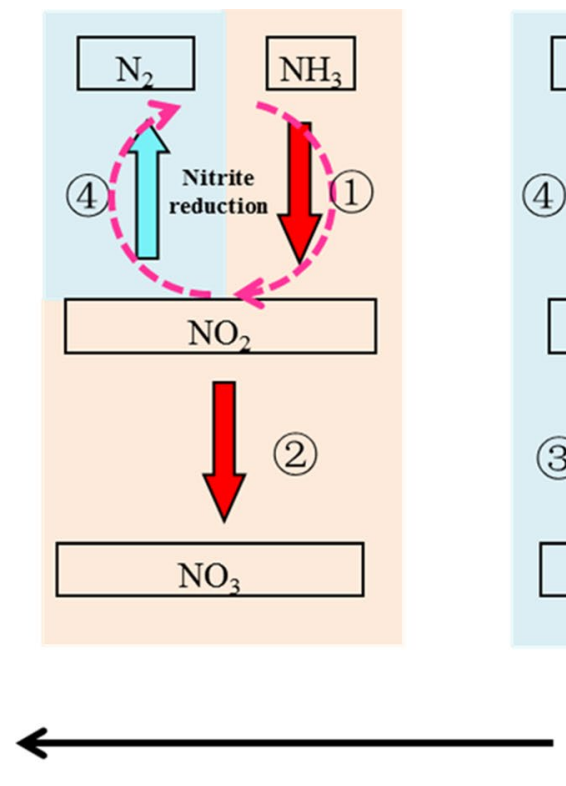

a $\mathrm{AOB} / \mathrm{NOB}>2$

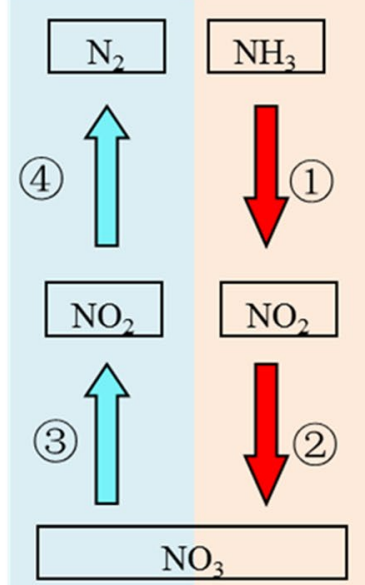

Balance

b $\mathrm{AOB} / \mathrm{NOB}=2$

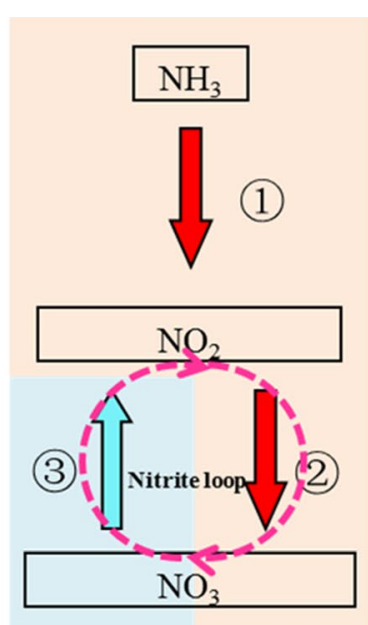

c $\mathrm{AOB} / \mathrm{NOB}<2$
Aerobic zone
(1) $\mathrm{AOB}$
(3) NaRB
Anoxic zone
(2) NOB
(4) NiRB

Fig. 5 a is a situation that the numerical ratio of $A O B / N O B$ is more than $2 ; \mathbf{b}$ is a situation that the numerical ratio of $A O B / N O B$ is $2 ; \mathbf{c}$ is a situation that the numerical ratio of $A O B / N O B$ is less than 2

As a conclusion, since the sequential oxidation of ammonium to nitrite then to nitrate, the growth balance between $\mathrm{AOB}$ and $\mathrm{NOB}$ plays a key role in optimization of nitrifying community. If the percentage of $\mathrm{AOB}$ is higher than that of $\mathrm{NOB}$, and the ammonia-oxidizing rate is higher than nitrite-oxidizing rate, nitrite as an intermediate will be accumulated. Nitrite in the effluent will consume the oxygen in the receiving water body, making it toxic to aquatic organisms. Furthermore, high nitrite is positively correlated with $\mathrm{N}_{2} \mathrm{O}$ emissions from aerobic zones of activated sludge in the presence of low DO concentration (Ahn et al. 2010). $\mathrm{N}_{2} \mathrm{O}$ is a greenhouse gas and has a significant effect on globe warming. However, fortunately, in the WWTPs surveyed, NOB numbers were 1.72-5.87 times as abundant as AOB, and NURs were 1.1-2.0 times higher than AURs. A large nitrite oxidation pool could be established in a nitrifying community. High nitrite oxidation potential guaranteed nitrite, produced from ammonium oxidizing by $\mathrm{AOB}$, will be quickly used by NOB. No intermediate was accumulated. Finally, a conceptual model was constructed to describe the bacterial growth balance in a nitrifying community which can explain the higher percentage of NOB in WWTPs.
However, it should be investigated further in the future work.

\section{Additional file}

Additional file 1. Additional figures.

\section{Abbreviations}

BNR: biological nutrition removal; WWTPs: wastewater treatment plants; FISH: fluorescence in situ hybridization; AOB: ammonia-oxidizing bacteria; NOB: nitrite-oxidizing bacteria; GHG: greenhouse gas; OUR: oxygen uptake rates; SUR: substrate uptake rates; AUR: ammonium uptake rate; NUR: nitrite uptake rate; MLSS: mixed liquor suspended solids; MLVSS: mixed liquor volatile suspended solid; DO: dissolved oxygen; CLSM: confocal laser scanning microscope; TN: total nitrogen; SND: simultaneous nitrification and denitrification; SRT: sludge retention time; HRT: hydraulic retention time.

\section{Authors' contributions}

QY designed and worked on bench as well as drafted the manuscript. DP developed hypothesis, supervised the work on bench and helped prepare the manuscript. Both authors read and approved the final manuscript.

\section{Authors' information}

Qian Yao is a doctoral student from School of Environmental and Municipal Engineering, Xi'an University of Architecture and Technology, Xi'an, China. Her key interest is in the field of nitrifying community structure in activated sludge systems. 
Dangcong Peng is a Professor of the School of Environmental and Municipal Engineering, Xi'an University of Architecture and Technology, Xi'an, China. He is currently working on Environmental Engineering, Wastewater Biological Treatment Technology and Water and Wastewater Treatment System Simulation.

\section{Author details}

1 School of Environmental and Municipal Engineering, Xi'an University of Architecture and Technology, Yanta Road 13, Xi'an 710055, China. ${ }^{2}$ Key Laboratory of Northwest Water Resource Environment and Ecology, Ministry of Education, Xi'an 710055, China.

\section{Acknowledgements}

The authors appreciated the technical help of the staff members of the WWTPs. We also thank the FISH team (Hanna Koch, Holger Daims et al.) at the Department of Microbiology and Ecosystem Science, Division of Microbial Ecology (Faculty of Life Sciences) in University of Vienna for the international FISH course for Qian Yao. This study was financially supported by Major Projects for Innovation of Science and Technology in Shaanxi Province (Grant No. 2011KTZB-03-03-03) and the National Water Special Project (No. 2013ZX07315-001-04)

\section{Competing interests}

The authors declare that they have no competing interests.

\section{Availability of data and materials}

The dataset(s) supporting the conclusions of this article is (are) included within the article [and its additional file(s)].

Received: 13 January 2017 Accepted: 16 January 2017

Published online: 23 January 2017

\section{References}

Adamczyk J, Hesselsoe M, Iversen N, Horn M, Lehner A, Nielsen PH, Schloter M, Roslev P, Wagner M (2003) The isotope array, a new tool that employs substrate-mediated labeling of rRNA for determination of microbial community structure and function. Appl Environ Microbiol 69:6875-6887. doi:10.1128/AEM.69.11.6875-6887.2003

Ahn JH, Kim SP, Park HK, Rahm B, Pagilla K, Chandran K (2010) $\mathrm{N}_{2} \mathrm{O}$ emissions from activated sludge processes, 2008-2009: results of a national monitoring survey in the united states. Environ Sci Technol 44:4505-4511. doi:10.1021/es903845y

Amann Rl, Krumholz L, Stahl DA (1990) Fluorescent-oligonucleotide probing of whole cells for determinative, phylogenetic and environmental-studies in microbiology. J Bacteriol 172:762-770. doi:10.1128/jb.172.2.762-770.1990

APHA (1995) Standard methods for the examination of water and wastewater, 19th edn. American Public Health Association, New York

Arciero D, Balny C, Hooper AB (1991) Spectroscopic and rapid kinetic studies of reduction of cytochrome $\mathrm{c554}$ by hydroxylamine oxidoreductase from Nitrosomonas europaea. Biochem 30:11466-11472. doi:10.1021/bi00112a014

Belser LW, Schmidt EL (1980) Growth and oxidation kinetics of three genera of ammonia oxidizing nitrifiers. FEMS Microbiol Lett 7:213-216. doi:10.1111/j.1574-6941.1980.tb01628.x

Colliver BB, Stephenson T (2000) Production of nitrogen oxide and dinitrogen oxide by autotrophic nitrifiers. Biotechnol Adv 18:219-232. doi:10.1016/ S0734-9750(00)00035-5

Copp JB, Murphy KL (1995) Estimation of the active nitrifying biomass in activated sludge. Water Res 29:1855-1862 doi:10.1016/0043-1354(94)00347-A

Daims H, Brühl A, Amann R, Schleifer KH, Wagner M (1999) The domainspecific probe EUB 338 is insufficient for the detection of all bacteria: development and evaluation of a more comprehensive probe set. Syst Appl Microbiol 22:434-444. doi:10.1016/S0723-2020(99)80053-8

Daims H, Nielsen JL, Nielsen PH, Schleifer KH, Wagner M (2001) In situ characterization of Nitrospira-like nitrite oxidizing bacteria active in wastewater treatment plants. Appl Environ Microbiol 67:5273-5284. doi:10.1128/ AEM.67.11.5273-5284.2001
De BD, Schramm A, Santegoeds MC, Nielsen KH (1998) Anaerobic processes in activated sludge. Water Sci Technol 37:605-608. doi:10.1016/ S0273-1223(98)00166-8

Dionisi HM, Layton AC, Harms G, Gregory IR, Robinson KG, Sayler GS (2002) Quantification of Nitrosomonas oligotropha-like ammonia-oxidizing bacteria and Nitrospira spp. from full-scale wastewater treatment plants by competitive PCR. Appl Environ Microbiol 68:245-253. doi:10.1128/ AEM.68.1.245-253.2002

Freitag TE, Chang L, Clegg CD, Prosser Jl (2005) Influence of inorganic nitrogen management regime on the diversity of nitrite-oxidizing bacteria in agricultural grassland soils. Appl Environ Microbiol 71:8323-8334. doi:10.1128/asm.71.12.8323-8334.2005

Fujita M, Tsuji K, Akashi A (2010) Temporal variation in maximum cell-specific nitrification rate. Water Sci Technol 61:2069-2073. doi:10.2166/wst.2010.978

Gregory SP, Shields RJ, Fletcher DJ, Gatland P, Dyson PJ (2010) Bacterial community responses to increasing ammonia concentrations in model recirculating vertical flow saline biofilters. Ecol Eng 36:1485-1491. doi:10.1016/j.ecoleng.2010.06.031

Hanaki K, Wantawin C, Ohgaki S (1990) Effects of the activity of hetetrophs on nitrification in a susupended-growth reator. Water Res 24:289-296. doi:10.1016/0043-1354(90)90003-O

Hao X, Heijnen JJ, Van Loosdrecht MC (2002) Model-based evaluation of temperature and inflow variations on a partial nitrification-anammox biofilm process. Water Res 36:4839-4849. doi:10.1016/S0043-1354(02)00219-1

Harms G, Layton AC, Dionisi HM, Gregory IR, Garrett VM, Hawkins SA, Robinson KG, Sayler GS (2003) Real-time PCR quantification of nitrifying bacteria in a municipal wastewater treatment plant. Environ Sci Technol 37:343-351. doi:10.1021/es0257164

Hooper AB, Vannelli T, Bergmann DJ, Arciero DM (1997) Enzymology of the oxidation of ammonia to nitrite by bacteria. Anton Leeuw Int J Gen Mol Microbiol 71:59-67. doi:10.1023/A:1000133919203

Li BK, Bishop PL (2003) Micro-profiles of activated sludge floc determined using microelectrodes. Water Res 38:1248-1258. doi:10.1016/j. watres.2003.11.019

Li BK, Irvin S, Baker K (2007) The variation of nitrifying bacterial population sizes in a sequencing batch reactor (SBR) treating low, mid, high concentrated synthetic wastewater. J Environ Eng Sci 6:651-663. doi:10.2175/193864706783763129

Limpiyakorn T, Shinohara Y, Kurisu F, Yagi O (2005) Communities of ammonia-oxidizing bacteria in activated sludge of various sewage treatment plants in Tokyo. FEMS Microbiol Ecol 54:205-217. doi:10.1016/j. femsec.2005.03.017

Lücker S, Schwarz J, Gruber-Dorninger C, Spieck E, Wagner M, Daims H (2014) Nitrotoga-like bacteria are previously unrecognized key nitrite oxidizers in full scale wastewater treatment plants. ISME J 9:708-720. doi:10.1038/ ismej.2014.158

Manser R, Gujer W, Siegrist H (2006) Decay processes of nitrifying bacteria in biological wastewater treatment systems. Wat Res 40:2416-2426. doi:10.1016/j.watres.2006.04.019

Mari KH, João PB, Robbert K, Dimitry YS, Mark CM (2012) Unravelling the reasons for disproportion in the ratio of $A O B$ and $\mathrm{NOB}$ in aerobic granular sludge. Appl Microbiol Biotechnol 94:1657-1666. doi:10.1007/ s00253-012-4126-9

Mobarry BK, Wagner M, Urbain V, Rittmann BE, Stahl DA (1996) Phylogenetic probes for analyzing abundance and spatial organization of nitrifying bacteria. Appl Environ Microbiol 63:2156-2162

Nielsen PH, Thomsen TR, Nielsen JL (2004) Bacterial composition of activated sludge-importance for floc and sludge properties. Water Sci Technolo 49:51-58

Off S, Alawi M, Spieck E (2010) Enrichment and physiological characterization of a novel Nitrospira-like bacterium obtained from a marine sponge. Appl Environ Microbiol 76:4640-4646. doi:10.1128/aem.00320-10

Okabe S, Hiratia K, Ozawa Y, Watanabe Y (1996) Spatial microbial distributions of nitrifiers and heterotrophs in mixed-population biofilms. Biotechnol Bioeng 50:24-35. doi:10.1002/sici.1097-0290

Pambrun V, Paul E, Spérandio M (2006) Modeling the partial nitrification in sequencing batch reactor for biomass adapted to high ammonia concentrations. Biotechnol Bioeng 95:120-131

Pommerening RA, Rath G, Koops HP (1996) Phylogenetic diversity within the genus nitrosomonas. Syst Appl Microbiol 19:344-351. doi:10.1002/ bit.21008 
Ramdhani N, Kumari S, Bux F (2013) Distribution of nitrosomonas-related ammonia-oxidizing bacteria and nitrobacter-related nitrite-oxidizing bacteria in two full-scale biological nutrient removal plants. Water Environ Res 85:374-381. doi:10.2175/106143013X13596524516022

Saunders AM, Albertsen M, Vollertsen J, Nielsen PH (2015) The activated sludge ecosystem contains a core community of abundant organisms. ISME J 10:11-20. doi:10.1038/ismej.2015.117

Siripong S, Rittmann BE (2007) Diversity study of nitrifying bacteria in fullscale municipal wastewater treatment plants. Water Res 41:1110-1120. doi:10.1016/j.watres.2006.11.050

Sun JK (2004) Estimation of active Nitrosomonas and Nitrobacter concentrations in activated sludge using nitrogenous oxygen uptake rate. Environ Eng Res 9:130-142. doi:10.4491/eer.2004.9.3.130

Szukics U, Abell GCJ, HodI V, Mitter B, Sessitsch A, Hackl E, Zechmeister-Boltenstern S (2010) Nitrifiers and denitrifiers respond rapidly to changed moisture and increasing temperature in a pristine forest soil. FEMS Microbiol Ecol 72:395-406. doi:10.1111/j.1574-6941.2010.00853.x

Takacs I, Fleit F (1995) Modeling of the micromorphology of the activated sludge floc: low DO, low F/M bulking. Water Sci Technol 31:235-243. doi:10.1016/0273-1223(95)00196-T

Wagner M, Rath G, Amann RI, Koops HP, Schleifer KH (1995) In situ identification of ammonia-oxidizing bacteria. Syst Appl Microbiol 18:251-264. doi:10.1016/S0723-2020(11)80396-6
Wagner M, Rath G, Koops HP, Flood J, Amann RI (1996) In situ analysis of nitrifying bacteria in sewage treatment plants. Water Sci Technol 34:237-244. doi:10.1016/0273-1223(96)00514-8

Wang XH, Xia Y, Wen XH, Yang YF, Zhou JZ (2014) Microbial community functional structures in wastewater treatment plants as characterized by GeoChip. PLoS ONE 9:e93422. doi:10.1371/journal.pone.0093422

Wells GF, Park HD, Yeung CH, Eggleston B, Francis CA, Criddle CS (2009) Ammonia-oxidizing communities in a highly aerated full-scale activated sludge bioreactor: betaproteobacterial dynamics and low relative abundance of Crenarchaea. Environ Microbiol 11:2310-2328. doi:10.1111/j.1462-2920.2009.01958.x

You SJ, Hsu CL, Chuang SH, Ouyang CF (2003) Nitrification efficiency and nitrifying bacteria abundance in combined AS-RBC and $\mathrm{A}^{2} \mathrm{O}$ systems. Water Res 37:2281-2290. doi:10.1016/S0043-1354(02)00636-X

Zhou X, Han YP, Guo XS (2013) Enhanced total nitrogen removal performance in a modified Orbal oxidation ditch system with internal nitrate recycle. Chem Eng J 228:124-131. doi:10.1016/j.cej.2013.04.096

Zhu GB, Peng YZ, Li BK, Guo JH, Yang Q, Wang SY (2008) Biological Removal of Nitrogen from Wastewater. In: Whitacre D (ed) Reviews of environmental contamination and toxicology, vol 192. Springer, New York, pp 159-195

\section{Submit your manuscript to a SpringerOpen ${ }^{\circ}$ journal and benefit from:}

- Convenient online submission

Rigorous peer review

Immediate publication on acceptance

- Open access: articles freely available online

- High visibility within the field

- Retaining the copyright to your article

Submit your next manuscript at springeropen.com 